\title{
Vicdan Kavramına Psikolojik ve Dini Yaklaşımlar
}

\section{$\ddot{O ̈ z}$}

Davut CEYLAN

Bu çalışmada vicdan kavramına dair batılı ve İslam düşünürlerinin görüşleri değerlendirilmekte ve yakın dönem mütefekkirlerinden olan Said Nursi'nin vicdana dair mülahazalarına yer verilmektedir. Vicdan fikri ana akım olarak iki temelde ele alınmaktadır. Bunlardan biri onun doğuştan var olan insani bir değer olduğudur. Diğeri ise edimsel olarak sonradan kazanıldığına dair görüştür. Batılı düşünürlerin birçoğu vicdanı edimsel kabul ederken İslam düşünürlerinin geneli onu varoluşsal beşeri bir değer görmektedir. Kuran'da "vicdan" ifadesi yer almamakla birlikte Said Nursi, onu insan ile Allah arasındaki iletişimin alt ucu olarak görmektedir. Allah insana peygamber ile hitap ettiği gibi ona vicdanından da seslenmektedir. Bu nedenle bozulmamış vicdanın mazhar olduğu her ilham/bilgi, ilahi bir kelamdır. Evrendeki varlıkları irade sıfatıyla yöneten Allah, kelam sıfatıyla vicdana etki etmekte ve eşyanın özüne uygun doğru davranışı insana bildirmektedir.

Anahtar kelimeler: Vicdan, hakikat, doğru davranış, ahlak, ilham/bilgi, insan.

\section{Psychologic and Religious Approaches to The Concept of Conscience}

\section{Abstract}

In this study, opinions of Western and Islamic thinkers, as well as the considerations of Said Nursi (a thinker of modern times) upon the concept of conscience, are evaluated. The idea of conscience as mainstream is evaluated on two bases. One of them; its being an innate humanistic value, while the other is its being acquired later. While a lot of Western thinkers accept it as acquired, the majority of Islamic thinkers consider it as an existential humanistic value. While the expression "conscience" does not show up in The Qur'an, Said Nursi sees it as the root of the communication between man and Allah. Like Allah calls out to man through the Prophet, He also calls out to him through his conscience. For this reason, any means to reach an unspoiled conscience lies through the holy word. Allah, who administrates the universe with His will, influences conscience with His words and informs man about the proper behaviour befitting a human being.

Keywords: Conscience, truth, proper behaviour, moral, information/inspiration, human.

\section{Giriș}

İnsan, madde ve mana boyutlarıyla karmaşık bir yapıya sahip olup, hayvanlara göre üstün bir kabiliyetle dünyaya gelmekte, bireysel ya da toplumsal yaşam içinde sahip olduğu bu kabiliyetlerini kullanarak hayatını devam ettirmektedir. Diğer canlılardan farklı olarak hem iyiye hem de kötüye kabiliyetli olup aşağıların en aşağısına düşecek veya yücelerin en yücesine çıkacak bir potansiyeli taşımaktadır. 
Yeryüzünde Allah'ın halifesi anlamında konuşan, düşünen, üreten ve eşyaya anlam veren insan, üstün bir istidada sahip olmakla beraber dünyada kan döken, yırtıcı ve korkunç bir varlık da olabilmektedir. Bu bağlamda yanlışa düşmesi doğasının gereği olan insanın, her şeyin iç yüzünü bilen ve fitratın yegâne sahibi olan Allah'la ne tür bir iletişimi olmaktadır? Allah'ın kullarıyla vahiyden başka iletişimi var mıdır?

Kâinatta her şeyi görerek yapan ve yarattı̆̆ her mahlûku bilerek terbiye eden bir zat "yapan bilir, bilen ise konuşur" kaidesi gereği yarattığı en mükemmel varlık olan insanlarla konuşmaması, onları kendi haline bırakarak doğru yola yönlendirmemesi mümkün görülmemektedir. Arıya balı vahyettiği, ipek böceğine dokumayı öğrettiği gibi, insana da hayatın belirsizlikleri içerisinde doğru yolu bildirmesi O'nun rahmet ve hikmetinin gereğidir.

Toplumların ihtiyaçlarına cevap verecek umumi kaideleri vahiy yoluyla bildiren Allah, hususi ihtiyaçlara cevap verecek meseleleri fitratın yalan ve yanlıştan en salim uzvu olan vicdana bildirmemesi mümkün değildir. Öyleyse âlemlerin Rabbi'ne muhatap olan vicdanın tartışılması kaçınılmaz hale gelmiş ve tarih boyunca birçok düşünür onu farklı yollardan tanımlamaya çalışmışlardır. Biz de bu bağlamda vicdan hakkındaki felsefi, psikolojik ve dini yorumları karşılaştırmalı olarak tartışmak istedik.

Şimdiye kadar vicdanla ilgili karşılaşılan önemli bir problem; insanın iç yaşantısında vicdanın hangi konumda olduğudur. Vicdan sonradan yaşantı yoluyla ortaya çıkan edimsel bir durum mudur? Yoksa insanın yaratılıştan sahip olduğu bir güdü müdür? Öte yandan Müslüman düşünürlerce insan psikolojisinin temel unsurları sayılan; kalp, nefis ve aklın, vicdan ile kurdukları dinamik ilişki de ayrı bir merak konusudur. Said Nursi'nin dinamik bir güç ve şuurlu fitrat olarak ifade ettiği vicdan kavramını genel olarak değerlendirmek ve vicdanla ilgili psikolojik ifadeleri de dikkate alarak Risale-i Nur adlı eseri bağlamında O'nun vicdan kavramına genel bakışını da ele almaya çalıştık.

\section{Etimolojik Olarak Vicdanın Tanımı}

Vicdan kelimesi Arapça bir ifade olup (v-c-d) kökünden türetilmiştir. Sözlükte "bulmak, zenginleşmek, sevmek, üzülmek, öfkelenmek" anlamlarındaki vecd kökünden mastar olan vicdan ve aynı kökten vücdân, cide gibi kelimeler "bolluk, rahatlık, zenginlik", vecd ise üzüntü ve sevgi manasına gelir. ${ }^{1}$

Vicdan Arapçada kullanılan sembolik bir ifadedir. "vecede" fiil kökünden türetilmiştir. "Vecede" fiilinin mastar kalıbı olan "el-vucud" beş duyu organı aracılığ 1 ile "bulma" yı ifade eder. Bir şeyin tadını, sesini, kokusunu, sertliğini bulmak,

1 Râgıb el-İsfahânî, el-Müfredât, Çıra Yay., İstanbul, 2012, s.1537. 
fark etmek, algılamak manasını ifade eder. ${ }^{2}$

Vicdan kelimesi, Arapça kullanımında bilişsel, duyuşsal ve hareki olarak pek çok psikolojik süreci ifade eder. Nefsin içsel gücünü ve yetisini ifade etmek için kullanılır. Arapçadaki geniş kullanım alanına karşın Türkçede bu kavram anlam daralmasına uğramıştır. Zira Türkçede tutum ve davranışların ahlâkiliği ile ilgili duygusal ve içgüdüsel durumlar için ifade etmektedir. ${ }^{3}$

İslam dini ilahi bir kanun olarak, itikat amel ve vicdaniyata ait hükümleri kapsamaktadır. Ahlak, İslami hükümlerin üç kısmından birini kapsamakta olduğu için İslam'a göre din ve ahlak başka şeyler değildir. Bu açıdan vicdanımız mazhar olduğu ilham ile doğruyu yanlıştan, iyiyi kötüden, hayrı şerden ayırt etmeye kadir ruhun manevi bir kuvvetidir. ${ }^{4}$

Vicdan konusuna benzer bir yaklaşım gösteren Musa Bilgiz'de; insanın vicdani duygusu, onun iyilikler karşısında sevinme, beğenme, hoşlanma, mutluluk duyma; kötülükler ve şerler karşısında ise üzülme ve nefret etmeye yönelik duygularıla ifade edilebilir demektedir. ${ }^{5}$

Hilmi Ziya Ülken'e göre ahlaki yaptırım hem içsel hem de dişsal olabilir. O'na göre ahlaki yaptırımda dışsal etki olarak övme, takdir etme, kötüleme ya da ayıplamayı görürken, içsel bir ahlaki yaptırım olarak vicdan azabı ve vicdani rahatsızl1k duymayı göstermektedir. ${ }^{6}$

Yokluğun ( $m a^{\prime}$ dum) zıddı olarak var olmak (v-c-d); bilinci, farkındalığ 1 , benlik şuurunu, kendi varlığının ve varlığın devamı için gerekenlerin verililiğini anlamlandırmayı, var olana değer atfetmeyi anlam alanı içerisine almaktadır. O yüzden 'var olmak' kökünden gelen vicdan terimi, insanın değer vererek var ettiği veya gaybi âlemden insana gelerek var olan duygu ve düşünceleri kapsıyor denebilir. Bunun sonucunda da vicdan, insanı oluşturan düşünce, duygu ve davranış boyutlarının tümünü kapsayan beşeri bir vasıf olarak ortaya çıkmaktadır. ${ }^{7}$

Özet olarak vicdanen bilme, aklen kavramaktan farklı bir şeydir. İnsan birçok hakikati vicdanen bilir. Akıl doğruyu ortaya koymada kıyas, mantık, hipotez, analiz gibi yöntemlerle hareket ederken vicdan bunlara muhtaç olmaksızın hakikatleri doğrudan bilir. Maviyi sarıdan gözle ayırt ettiğimiz ve acılı ve acısız yemeği dille

2 Abdulvahit İmamoğlu, "Vicdan Kavramının Psiko-Sosyal Tahlili”, Akademik İncelemeler Dergisi, Cilt:5 Sayı:1 2010, s.128.

3 Abdurrahman Kasapoğlu, “Kur'an'a Göre Vicdanın Kaynağı ve İşlevleri”, Akademik Araştırma Dergisi, Sy. 18, 2003, s.131.

4 Ömer Nasuhi Bilmen, "Muvazzah İlm-i Kelam”, İstanbul, 1972, s.68.

5 Musa Bilgiz, Kur'an Açısından Vicdan ve Değeri, Beyan Yayınları, İstanbul, 2007, s.46.

6 H. Ziya Ülken, Ahlak, İstanbul, 1946, s.158.

7 Zeynep Hümeyra koç, "Vicdanın Ahlaki Ve Teolojik Temelleri”, (yüksek lisans tezi) Ankara, 2015, s.182. 
fark ettiğimiz gibi, vicdanla da hayır ve şerrin, doğru ve yanlışın farkına varırız. Bütün bu tanımlardan hareketle vicdan, insanın kendisinin ya da bir başkasının işlemekte olduğu fiil ve davranışlar hakkında ortaya koyduğu değer yargılarıdır. ${ }^{8}$

\section{2. İslam Düşünürlerinde Vicdan Yorumları}

İslam düşünürlerinde vicdanın doğuştan getirilen fitrî bir yeti olduğu düşüncesi hâkimdir. Bu görüşlerini düşünürler, ayet ve hadislere dayandırarak temellendirmeye çalışmışlardır. "Hayır ve erdem kalbin tatmin olduğu şeydir, şer ve kötülük de nefsini rahatsız eden şeydir" sözü hadis olarak Hz. Peygambere dayandırılmaktadır. Kur'an-1 Kerim'de bulunan "Nefse fenalığ $ı$ ve iyiliği ilham edene and olsun ki", "Biz insana hayır ve şer yollarını göstermedik mi?" ayetler de yine vicdanın doğuştanlığ fikrini savunanlarca delil olarak gösterilmektedir. ${ }^{11}$

Kur'ân-1 Kerîm'de vicdan kelimesi geçmemekle birlikte birçok ayette insanda bulunan ve onun iradî fiillerini ahlâk ölçülerine göre denetleyen, iyilik yapmaktan sevinç, kötülük yapmaktan sstırap duyan bir ahlâkî melekeden söz edildiği, tövbenin de böyle bir vicdanî hesaplaşmanın ürünü sayıldığ 1 görülür. ${ }^{12}$ Hadislerde ise genel itibariyle vicdan kavramının karşılığı olarak 'kalp' ifadesi kullanılmaktadır.

Ali Şeriati, vicdanı insanın öz benliği olarak görmektedir. Kendim dediğinde insanın kendisinde gömülü olan ve özgür ben olarak hissettiğidir. ${ }^{13}$ Vicdan iç ses olarak hesapçı ve faydacı bir motivasyondan uzak olarak insanın öz benliğinde var olan devrimci bir güçtür. ${ }^{14}$

Bazılarına göre ise hür vicdan, toplumun geleneklerine ya da kurulu statik düzene sık sık başkaldıran gizli bir otorite olarak görmektedir. Fakat vicdanın oluşumunu tek sebeple açıklamak doğru olmaz. Onun şekillenmesinde çevresel faktörlerle beraber din olgusu da önemli bir yer tutmaktadır. Sorumluluğun merkezi olan vicdanın ortaya çıkışı dini inançlardan da kaynaklanmaktadır. ${ }^{15}$

Kuçuradi ise vicdanı değer atfetme veya doğru değerlendirme şeklinde ifade etmektedir. O'na göre vicdanın sesi karanlıkta çakan ani bir şimşek gibidir. Ans1zın çakıp kaybolan bu şimşeğin 1şığı karşı taraftaki varlıkların dağ mı ova mı yoksa tepelik mi olduğu hakkında ipuçları verir. Bilinçli ve duyarlı bir insan aynı ta-

8 Abdulvahit İmamoğlu, "Vicdan Kavramının Psiko-Sosyal Tanımı”, Akademik İncelemeler Dergisi Cilt:5 Sayı:1 2010, s.130.

9 Şems/ 8.

10 Beled/10.

11 Yusuf Ziya Çağl1, "İslam Dininde Vicdanın Mahiyeti”, Sebilürreşad, c.XII,Çağl1, sy.289., s.212.

12 TDV, İslam Ansiklopedisi, İstanbul, 2013, s.101.

13 Ali Şeriati, İnsanın Dört Zindanı, Çev: H. Hatemi. İstanbul, 1984. s.78.

14 Şeriati, a.g.e., s.88.

15 Abdülkerim Bahadır, İnsanın Anlam Arayışı Ve Din, insan yay, İstanbul, 2002, s.104. 
rafa sabırla bakmaya devam ederse bir süre sonra oradaki varlıkların ne olduğunu detaylarıyla birlikte anlayıp haritasını çıkarabilir. İşte vicdanın bu ipuçlarına karşı insan olay ve davranışlar karşısında "ezbere değer biçme" yoluna gitmemelidir. ${ }^{16}$

Erol Güngör'e göre vicdan, doğruyu yanlıştan iyiyi kötüden ayırma gücü, kişinin iç dünyasındaki yargılama gücü olarak tarif edilmektedir. ${ }^{17}$

İlhami Güler, vicdanı insanı hayvandan ayıran ve onu üstün kılan temel bir özellik olarak görmektedir. Kuran, insana teklif olarak sunulan dini insanın vicdani özü üzerine kurmaya çalışmaktadır. İnsana verilen büyük emanet ${ }^{18}$ de vicdani özdeki bu aktüelleşmedir. Bu anlamda vicdani sorumluluk sadece insana yüklenmiş olmaktadır. Güler'e göre hakiki bir vicdan daima diridir. Hakiki bir mümin veya insan olmanın temel koşulu vicdanın canlı tutulması, aktif kılınması ve işletilmesidir. O'na göre Kur'an'da 'ataların yaşam koşullarına uyma' şeklinde ifadesini bulan statik kültürel yapılar veya içselleştirilmiş otoriteler vicdanın özündeki dinamizmi ve hakkaniyeti perdelemektedirler. ${ }^{19}$ Aynı zamanda Tanrı ile vicdan arasında ontik bir bağ vardır. Tanrı mutlak kudret olduğu kadar yoğunlaşmış mutlak vicdandır (adalet). Vicdanın kaynağı ise Kur'an'a göre (mahiyeti meçhul) Tanrı'nın yaratılışta bize üflediği ruh ${ }^{20}$ 'tur. Güler'e göre vicdanın keşfettiği değerlerin Tanrı'dan vahiy yoluyla gelen emirlerle paralellik arz etmesi vicdan ile Allah arasındaki ontik bağın göstergesidir. ${ }^{21}$

Habil Şentürk'e göre ise Piaget'in ‘özerk ahlak' dediği kavram vicdandan başka bir şey değildir. Vicdan insanın içindeki mahkeme olduğu gibi, irade de bu mahkemenin verdiği karardır. ${ }^{22}$

\section{Batı Dünyasının Vicdan Kavramına Bakışı}

Vicdan kavramının çıkışı köken olarak eski Yunan'dadır. Sonradan Avrupa'ya yayılarak batı düşünce sisteminde yerini almıştır. Orta çağ Avrupa'sında kilisenin egemenliğinde vicdan kavramı çok arka planda kalmakla beraber insanın doğuşu anlamındaki Rönesans ile tekrar canlanarak insanı tanımlamada ve insani var oluşta merkezi bir yer edinmiştir. ${ }^{23}$ Öte yandan ahlak ve vicdan konusunda filo-

16 İoanna Kuçuradi, Etik, Ankara, 1988, s.20-21.

17 Erol Güngör, Ahlak Psikolojisi ve Sosyal Ahlak, Ötüken Yay, İstanbul,1995, s.55-57.

18 Ahzab,33/72. "Biz emaneti göklere yere ve dağlara arz ettik. Onlar onu yüklenmeye yanaşmadılar, ondan korktular da onu insan yüklendi. O cidden çok zalim, çok cahil bulunuyor."

19 İlhami Güler, Vicdanın Kendini Kandırma Halleri Olarak Vicdansızlık, Eskiyeni, Sonbahar 2010, say1: 19, s.101. (26-28 Kasım 2010 tarihlerinde Samsun'da düzenlenen “I. Uluslararası Bilim, Ahlak, Sanat Bağlamında Çağdaş İslam Algıları” sempozyum bildirisi)

20 Hicr, 15/29.

21 İlhami Güler, a.g.m. s.105.

22 Habil Şentürk, İslami Hayatın Psikolojik Temelleri, İz Yay., İstanbul, 2013, s.101.

23 Zeynep Hümeyra Koç, Vicdanın Ahlaki Ve Teolojik Temelleri, (Yüksek Lisans Tezi) Ankara, 2015, s.179. 
zoflar ikiye ayrılır. Bir kısmı ahlak yasalarının insanda doğuştan var olduğunu, diğer kısmı ise sonradan kazanılan edimsel bir durum olduğunu savunur. Özellikle John Locke'un “tabula rasa” tezi buna örnektir.

Locke'e göre insan zihni bilgi açısından doğuştan getirdiği hiçbir şeye sahip değildir. Bütün bilgiler sonradan deney yoluyla elde edilmektedir. ${ }^{24}$ Aynı zamanda Locke'a göre insan için iyi ve kötü ondan aldığı hazza bağlıdır. İnsana haz veren her şey iyidir. Bu yüzden iyi ve kötü özneldir. ${ }^{25} \mathrm{Bu}$ bağlamda O’na göre ahlaki ve vicdani değerlerin doğuştan insan zihninde bulunmamaktadır. Bilginin deneysel yollarla elde edilmesine paralel şekilde ahlaki değerler de sonradan kazanılan öznel bir durumdur. Tüm insanların kabul ettiği evrensel bir ahlak düzeninin olmayışı da buna delilidir. Fakat sadece haz ve akıl vicdan değerlerin oluşmasında yetersiz kalacağı için tanrısal bir iradenin ahlak yasası koyarak yaptırım uygulayacağını da ileri sürmüştür. ${ }^{26}$

Heideger'e göre vicdan, bir şeyleri anlamamızı sağlayan ve onları açarak ortaya koyan bir özelliktir. Vicdanın detaylı bir analizi onun bir "celp" olduğunu ortaya koyar. 'Celp sözün bir halidir. Vicdanın celbi, Dasein'in (varoluş) kendi en zati varlık-olma- imkânına celp etme karakterine sahiptir ki, onun minvali en zati vecibe -içinde olmaya çağrıdır. Celp, hadiselerden haber vermez; o, herhangi bir beyanda bulunmaksızın celp eder. Celp, tekinsiz bir hal olan sükût halinde konuşur. $O$ bu halde konuşur, çünkü celp, celp edileni herkesin umumi lakırdısı içinde değil, aksine, tam da oradan geriye, yani varoluşsal varlık-imkânının ketumiyetine çağırır.» $^{27}$

J.J. Rousseau ise vicdana dair şu sözleri söylemiştir: "Vicdan, vicdan ... Ey ilahi içgüdü! Ölümsüz ve semavi sada! Zavall ve cahil yaratıkların en güvenilir rehberi, sensiz hayvanlardan farksız olur, kötülükten kötülüğe sürüklenir, özsüz bir akıl gücünün ve yasasız bir aklın sürüklemeleriyle, üzücü sonların ve ağır yanlışların avı olurdum. $" 28$

Rousseau'nun ahlâka dair konularda aklı ön planda tutmaktan daha ziyade gönlü ve vicdanı kendisine kılavuz yaptığını görmekteyiz. O'na göre vicdan deruni bir ses veya 1şıktır. İnsanı doğruya götürür. Fakat ahlaki sorumluluklarını sürekli çiğneyen birisinde vicdani hassasiyet zarar görmektedir. Dolaysıyla vicdan

24 John Locke, İnsan Anlığı Üzerine Bir Deneme, Çev: V. Hacıkadiroğlu, Kabakı Yay. İstanbul, 1992, s.63.

25 John Locke, a.g.e. s.148.

26 Mustafa Cihan, “John Locke’un Ahlak Üzerine Düşünceleri”, Kazım Karabekir Eğitim Fakültesi Dergisi, 2004, Sayı:10, s.112.

27 Martin Heidegger, Varlık ve Zaman, Çev: Kaan H. Ökten. İstanbul, 2009. s. 285.

28 Rousseau, "Emile”, Çev. Mehmet Baştürk-Yavuz Kızılçim, Babil Yayınları, Erzurum, 2002, s. 186 
O’na göre yanlış yapmaktan koruyan iç ölçü ve bekçidir denilebilir. ${ }^{29}$

Kant; ahlak ve vicdan konusunda çığır açmış ve sonraki düşünürlere paradigma sunacak çalışmalara yer vermiş̧ir. Kant'a göre vicdan, kişinin kendi yapıp ettiklerini mevcut ahlâk yasası içinde değerlendirdiğinde duyduğu "acı verici bir duygudur." ${ }^{30}$ Kişi yasalara aykırı bir davranış yaptığında ne tür bir gerekçe bulursa bulsun susturamadığ içsel bir davacı vardır. Kendini aklamak için yaptığı tüm uğraşlara rağmen sesini susturamadığı bu şaşırtıcı yetinin yargılamalarından insan kaçamamaktadır. Olmuş bitmiş bir eylemde insana sürekli pişmanlık duygusu yaşatan bu yeti vicdandır. ${ }^{31}$

Kant'ın ahlak ve vicdan konusundaki en temel ifadesi "koşulsuz buyruk" kavramıdır. Şarta dayalı olarak sunulan her ahlaki önerme O'na göre ahlaki değildir. Ahlaki ödev kendiliğinden var olan bir nitelik taşımalıdır. Aksi durumda araçsal hale gelecektir. Başkasından türetilmeyen temelini kendinde bulan bu yasaya koşulsuz buyruk ifadesini kullanır. Mantıkta "Bütün, parçalarından büyüktür" ilkesi ispatlanmaya ihtiyaç duymayan apaçık bir doğruysa, etiğin temelinde de böyle bir doğru olmalıdır. Bu bağlamda vicdan, O'na göre kendi kendisi için sorumluluk olan bir koşulsuz buyruk anlamına gelir. ${ }^{32}$

İmmanuel Kant'ın meşhur sözü de konuya 1şık tutar niteliktedir. “iki şey, üzerlerine sık sık eğilip ısrarla düşünülürse, insanın ruhsal yapısını hep yeni, hep artan bir hayranlık ve korkunç bir sayglyla dolduruyor: üzerimdeki yıldızlı gök ve içimdeki ahlâk yasası."

Kant'ın bahsi geçen koşulsuz buyruk ve doğal ahlak yasası gibi kavramlarından yola çıkarak onun vicdanı nesnel olarak ele aldığ 1 söylenebilir. Zira harici bir etki veya duyumlarla ortaya çıan öznel bir edinim değil, cevheri bir mahiyet taşımaktadır.

H. Z. Ülken, Spinoza için bütün gayesinin özgür bir yaşam inşa etme noktasında bireyin kendi kendisinin efendisi olması ve kendi gücünü merkeze alması olduğunu söylemektedir. Bu yüzden onun asıl ahlakını, rasyonel bilginin hayatın akışına tatbiki olarak görmek mümkündür. ${ }^{33}$ Spinoza düşünce paradigmasının merkezine Tanrı'yı koyduğu için onun etik, ahlak gibi kavramlarını da bu bağlamda düşünebiliriz. Fakat onun "Tanrı" kavramı doğayla içkin halde bulunan ve her

29 Ali Kahveci, J.J. Rousseau'da Ahlâkî Vicdan ve Değeri, Çukurova Üniversitesi Illahiyat Fakültesi Dergisi, 12 (1), 2012, s.211.

30 İmmanuel Kant, pratik aklın eleştirisi, (çev: İoanna Kuçuradi, Ülker Gökberk, Füsun Akatl1), Türkiye felsefe kurumu, Ankara,1994 s.108.

31 Kant, a.g.e. s.107.

32 Özge Özaydın, "İçimdeki Ahlak Yasası: Kant'ın Ahlak Kuramı Üzerine Eleştirel Bir İnceleme”, Felsefe Arşivi, say1.34, 2011, s.99-102.

33 Hilmi Ziya Ülken, "Spinoza ve Etika Çevirisi Üzerine Birkaç Söz”, Spinoza, Etika, Fransızcadan Çev: Hilmi Ziya Ülken, 2. Baskı, Ankara, Dost Kitabevi, 2006, s.26. 
şeyin özünü belirleyen evrensel yasa anlamındadır. ${ }^{34}$

Spinoza'ya göre tabiatta zorunsuz hiçbir şey yoktur. Orada her şeyin meydana gelmesi tanrısal tabiatın zorunluluğu ile ortaya çıkmaktadır. ${ }^{35} \mathrm{O}$ 'na göre varlık, Tanrı tarafından meydana getirildikleri nizamdan başka hiçbir şekil veya nizamda ortaya çıkamazlar. ${ }^{36} \mathrm{Bu}$ bağlamda insanın konumu da bir derece netlik kazanmaktadır. Zira Deleuze'a göre Spinoza, insanın doğasında herhangi bir şeye sahip olmadığını düşünmektedir. O'na göre insan akıllı ve özgür değildir. Konuşan bir hayvan tanımlaması da Spinoza'da görülmemektedir. ${ }^{37}$

Spinoza insanın özgürlük ve mutluluğunun yolunu da Tanrı'nın yasalarını sezgi yoluyla edinmeye bağlamaktadır. ${ }^{38}$ O'na göre insan sürekli tutkulara maruz kalarak onlara esir olmak durumundadır. Bu tutkularından kurtularak tanrısal iradeye uyum sağladı̆̆ ölçüde doğrunun ve iyinin özüne ulaşabilir. ${ }^{39}$

Erich Fromm ise vicdanı kaynağına göre otoriter ve humaniter olarak ikiye ayırır. O'na göre otoriter vicdan, içselleştirilmiş bir dışsal otoritenin sesidir. $\mathrm{Bu}$ vicdan gücünü anne babaya, devlete ya da belli bir kültüre duyduğu hayranlık ve korkudan almaktadır. O yüzden doğruya göre değil, dişsal otoritenin isteğine göre hareket eder. Gerçek bir vicdanı temsil etmez. Erich Fromm'a göre otoriter vicdan, Freud'un süper ego adını verdiği benlik birimidir. ${ }^{40}$ Hümaniter vicdan ise erdemin ve mutluluğun doğru yolunu gösteren insani bir işarettir. ${ }^{41}$

\section{Said Nursi'ye Göre Vicdan Kavramı}

Vicdan Said Nursi'nin eserlerinde üzerinde durduğu önemli bir kavramdır. İnsan-Allah ilişkisinde vicdan kritik bir önemdedir. Zira O'na göre Allah'ı bildiren dört büyük öğreticiden birisi de vicdandır. Aynı zamanda insan vicdanı, fitratın kanunudur. Allah özgür bıraktığı insana oradan seslenerek ona evrenin nizamını bildirmektedir. Aynı zamanda vicdan, Nursi’ye göre mahiyetini yitirerek yanlışı doğru olarak da gösterebilmektedir. Bu noktada Said Nursi'nin Risale-i Nur adlı eserine göre vicdan kavramını birkaç açıdan ele almaya çalışacağız.

34 Karen Armstrong, Tanrı'nın Tarihi, Çev: Oktay Özel, Hamide Koyukan, Kudret Emiroğlu, 2. Bask1, Ankara, Ayraç Yayınları, 2008, s.445473-.

35 Baruch Spinoza, Ethica, Çev: Hilmi Ziya Ülken, Dost Kitabevi Yay, Ankara, 2011, s.60.

36 Baruch Spinoza, a.g.e, s.64.

37 Gilles Deleuze, Spinoza Üzerine Onbir Ders, Kabalc1 yay, İstanbul, 2008, s.79.

38 Ahmet Cevizci, Etiğe Giriş, Paradigma, İstanbul, 2002, s.116, Spinoza, a.g.e. s.285.

39 Yaşar Türkben, Spinoza'ya Göre Tanrı Ve İrade Özgürlüğü, Fırat Üniversitesi İlahiyat Fakültesi Dergisi,15,1 2010, s. 124.

40 Erich Fromm, Erdem ve Mutluluk, çev:Ayda Yörükan, İş bankası kültür yay, İstanbul, 1994, s.172-173.

41 Erich Fromm, a.g.e. s.189. 


\section{Vicdan - Allah ilişkisi}

Nursi'ye göre vicdan şuurlu bir fitrat olup insandan Allaha açılan bir penceredir. O’na göre vicdanın Allah'a karşı doğal bir yönelimi vardır. İnsanda mükemmele karşı duyulan arzu ve istek esasında vicdanın Allaha olan aşkıdır. Zira insanın özünde bulunan acziyet ve yetersizlik onu sürekli bir dayanak ve yardım noktasına itmektedir. Bu iki etki de vicdanın yüzünü her zaman Allaha yöneltmektedir. ${ }^{42}$

Öte yandan Nursi'ye göre evrende mutlak ve harici bir ilahlık hükmetmektedir. Canlı ve cansız varlıkların tam itaatle uydukları ilahi düzen bu ilahlığın göstergesidir. Aynı zamanda insanlık tarihi boyunca insanların sürekli tapınma nesnelerine yönelmeleri, şükür ve minnettarlık duygularını bir varlığa takdim etmeleri de nesnel anlamda Tanrısal bir iradenin doğadaki etkisidir. ${ }^{43} \mathrm{Bu}$ irade, cansız varlıkları cebren etkisi altına aldığı gibi, hayvanları da ilahi bir sevk (içgüdü) ile yönetmektedir. Nursi evrendeki bu düzeni Allah'ın irade sıfatından gelen kevni şeriat, şeriat-1 fitriye ve sünnetullah olarak tanımlıyor. ${ }^{44}$ Öte yandan insanların davranışlarını düzenlemek üzere Allah'ın kelam sıfatından vahiy yoluyla gelen kitabi şeriat vardır. Nursi bu şeriatı, kevni şeriatın insandaki uzantısı olarak görmektedir. Bu bakımdan evreni etkisi altına alan tanrısal iradenin uzantısı insan vicdanında da ortaya çıkmakta ve onun davranışlarına, evrenin doğasına uygun şekilde yön vermektedir. ${ }^{45}$ Nursi ye göre uyanık ve bozulmamış bir vicdandan gelen her ses, mikro çapta ilahi birer mesajdır. Allah, kelam sıfatı gereği insana sürekli vicdanından hitap etmektedir. O'na göre “Ĕger yeryüzündeki a ğaçlar kalem deniz de mürekkep olsa arkasından yedi deniz daha ona katılsa Allah 'in sözleri (yazmakla) yine de tükenmez." ${ }^{46}$ ayetinde sonsuz sayıdaki ilahi kelamların bir anlamı da vicdanlardaki bu ilhamlardır. ${ }^{47}$ Said Nursi'nin vicdana dair bu bakış açısından hareketle, O'nun meşru ahlak yasalarını insan ile eşya arasında kurulan en ideal davranış biçimleri olarak gördüğünü söylemek mümkündür.

Vicdanın Allaha olan bu arzusu çekirdeğin yeşerme isteği, yumurtanın içindeki hayat meyli veya donan suyun genişlemeye olan eğilimi gibidir. Bu meyiller ilahi iradeden gelen tekvini emirler olması gibi Said Nursi’ye göre vicdandan çı-

42 Said Nursi, Mesnevi-i Nuriye, çev:Abdülmecid Nursi, Diyanet İşleri Başkanlığg, İstanbul, 2015, s.351.

43 Said Nursi, Şualar, Envar neş. İstanbul, 2011, s.150.

44 Said Nursi, Mektubat, Türkiye Diyanet Vakf1, Ankara, 2016, s.507. Said Nursi, Sözler, Türkiye Diyanet Vakfi, Ankara, 2016, s.421-426. s.901. (Nursi'ye göre evrendeki fizik yasalar1, Allah'1n irade sıfatından (Mürid) gelen emirlerdir. Maddenin ruhu hükmündeki bu kanunlar, O'nun irade s1fatının eşya üzerindeki etkisidir.)

45 Said Nursi, Mesnevi-i Nuriye, çev: Abdülmecid Nursi, Diyanet İşleri Başkanlığı, İstanbul, 2015, s.346.

46 Lokman, 31/27.

47 Said Nursi, Şualar, Envar neş. İstanbul, 2011, s. 125. 
kan arzu ve emeller mutlak varlığ 1 isteyen emarelerdir. Vicdanın bu eğilimi, Said Nursi'ye göre çekirdeğin yeşermek, yumurtanın canlanmak veya donan suyun genişlemek eğilimine benzer bir durumdur. ${ }^{48}$ Bu bağlamda Nursi'ye göre vicdan, doğadaki Tanrısal iradenin vesayetini istemekte ve onun egemenliğine girmek istemektedir.

Allah'ın insanla olan ilişkisi Nursi ye göre bir padişahın kendi teb'asından biriyle mektup veya telefon yoluyla yaptı̆ğ görüşme gibidir. Allah'ın mütekellim (konuşan) sıfatı gereği her an var olan bir konuşması vardır. İnsanların kalpleri birer alıcıdır ve her an meydana gelen ilahi sinyalleri almaktadır. ${ }^{49} \mathrm{Bu}$ sinyaller vicdanda sezgi şeklinde, akılda ise fikir şeklinde ortaya çıkmaktadır ki ilham denilen bilginin kaynağı bu ilahi mesajlardır. ${ }^{50}$ Bununla beraber O'na göre her insandaki alıcılar birbirinden farklıdır. İnsanların Allaha yakınlığı ve ruhundaki istidat ölçüsünde ilahi mesajın boyutu değişmektedir. Bu bağlamda ortalama bir insana, evliyaya ve peygambere yapılan konuşmalar farkl1lık arz eder. Bu sebepten peygamberin muhatap olduğu konuşma, hiç bir beşerin sahip olamayacağ vahiy mertebesidir. ${ }^{51}$

İnsanların dualarıyla yaptıkları ilahi yönelime Allah, insana yine vicdanından konuşarak cevap verir. İnançlı veya inançsız fark etmeksizin her talep Allah için aynı niteliktedir. $\mathrm{Bu}$ açıdan fiili birer dua olan tüm bilimsel çalışmalarda Allah bilgiyi vicdana ilham ederek bireye cevap vermektedir. ${ }^{52} \mathrm{Bu}$ bağlamda Gazali'nin meşhur “Bilginin kaynağ Allah 'tır.” ifadesiyle Nursi'nin 'vicdani ilhamlar' görüşünün paralellik arz ettiğini söyleyebiliriz.

\subsection{Vicdan - İnsan İlişskisi:}

Nursi'ye göre insandaki vicdan akıl ve kalp arasında dinamik bir ilişki vardır. O’na göre kalp, ilahi mesajın ilk ulaştığı noktadır. Bu mesajın mahiyeti net olarak bilinmemekle beraber, fikir ve his (düşünce ve duygu) şeklinde iki çeşit somut formu vardır. Düşünce formatı akılda, duygu formatı ise vicdanda ortaya çıkmaktadır. $^{53}$

İnsanın bedeni ile kalbi arasında da ilginç bir ilişki vardır. Nursi’ye göre cesedimizdeki kanı pompalayan biyolojik kalbimiz bu göreviyle diğer organlara hayat vermekte ve insan hayatının devamını sağlamaktadır. $\mathrm{Bu}$ yönüyle

48 Said Nursi, Mesnevi-i Nuriye, Çev: Abdülmecid Nursi, Diyanet İşleri Başkanlığı, İstanbul, 2015, s.351.

49 Said Nursi, Sözler, Türkiye Diyanet Vakfı, Ankara, 2016, s.159. Şualar, s.124.

50 Said Nursi, İşaratül İ'caz, çev:Abdülmecid Nursi, Diyanet İşleri Başkanlığı, Ankara, 2015, s. $230-232$.

51 Said Nursi, Şualar, Envar Neş., İstanbul, 2011, s.125.

52 Said Nursi, Sözler, Türkiye diyanet vakfi, Ankara, 2016, s.380, s.392,

53 Said Nursi, İşaratül İ'caz, çev: Abdülmecid Nursi, Diyanet İşleri Başkanlığı, Ankara, 2015, s.230. 
biyolojik kalp bir hayat makinesidir. Buna benzer şekilde manevi kalp de insanın davranışlarını, hallerini ve maneviyatını, hayat nuru ile canlandırır ve 1şıklandırır. İnsanın biyolojik olan hayvani bedenine, beşeri bir sıfat kazandırarak insani hayat seviyesine çıkartır. Bu sebepten çeşitli sebeplerle kalbi ölmüş biri Said Nursi'ye göre hareket eden bir heykeldir. ${ }^{54} \mathrm{Bu}$ bağlamda vicdanı kalbin his merkezi olarak düşünürsek insana hayat veren hislerin kaynağının vicdan olduğunu söylemek mümkündür.

Said Nursi insanda beş duyudan başka iki duyunun daha varlığından bahsetmektedir. Bunlar 'sevk' ve 'şevk' hisleridir. İlahi sevk olarak adlandırılan bu altıncı hissimiz insanın kendiliğginden yaptığı bilinçdışı davranış ve yönelimlerdir. Bu yönüyle psikoloji'deki içgüdü kavramıyla örtüşmektedir. Yedinci his olan 'şevk' ise insanın bir işe duygularını katarak teşebbüs etmesidir. Nursi'ye göre bu iki hissin kaynağ 1 da vicdandır. ${ }^{55}$

Risale-i Nur'da vicdan ve insan ilişkisi maddi ve manevi bağlamda da ele alınmaktadır. Nursi'nin tabiriyle insanın mülk ve melekût denilen iki yönü vardır. Mülk fiziksel evrenle ilgili insanın maddi yönüdür. Melekût ise fizikötesi evrenle ilgili olan insanın manevi tarafidır. Bu bağlamda insana mülkiyet (fiziksel) tarafından bakarsak insan bedeni, vicdanı kuşatmış ve içine almıştır. Eğer insana melekût yönüyle bakarsak, vicdan insanı içine almıştır. Zira duygu, düşünce ve davranışlarıyla beraber hal ve tavırlarına vicdan hükmetmektedir. ${ }^{56}$

\subsection{Vicdanın Bozulması}

Öte yandan Nursi'ye göre insan vicdanı bozulmaya veya maniple edilmeye müsaittir. "Vicdanı tefessüh etmek, bozulmak" gibi tabirler ona aittir. Çürümek, bozulmak gibi ifadelerle Nursi vicdanın mahiyetinin zarar gördüğünü belirtir. Ona göre vicdan, Allah'a imandan sonra işlenen günahlar, isyankâr tavırlar ve heveslerini gaye edinmek gibi içsel nedenlerle bozulmaktadır. Zira Nursi ye göre insan bu süreçte nefis, heva, benlik gibi bazı cihazların etkisiyle bir takım nesnelerin egemenliğine girmektedir. Zamanla (bireysel ya da kollektif) bu nesneler, kişi tarafından içselleştirilmekte ve onun dünyasında hükmedici olarak kişiliğin hâkim faktörü halini almaktadırlar. Bu bağlamda insan için doğru, içselleştirdiği varlığın isteği olmaktadır. "Hevasını ilah edineni gördün mü??"57 ayeti Nursi'ye göre insanın düştüğü bu sapmayı ifade etmektedir. ${ }^{58}$

54 Said Nursi, a.g.e, s.232.

55 Said Nursi, Mesnevi-i Nuriye, çev: Abdülmecid Nursi, Diyanet İşleri Başkanlığı, İstanbul, 2015, s.351.

56 Said Nursi, a.g.e. s. 160 .

57 Furkan, 25/43

58 Said Nursi, Sözler, Türkiye Diyanet Vakfı, Ankara, 2016, s.669. s.589. Said Nursi, Lemalar, Envar neş. İstanbul, 2011, s.6. 
Said Nursi'ye göre uzun süre bu etkinin altında kalan bir vicdan, hakikat orijinini tamamıla kaybedecektir. O'na göre Kur'an, "kalpleri mühürlemek",59 kavramıyla insanın bu durumunu ifade etmektedir. Zira artık kişinin vicdanında doğru ve yanlışı ayırt edecek istidat kalmamıştır. Vicdanın görünmeyene (gayba) bakan yüzü kapanmıştır. ${ }^{60}$ Bediüzzaman günah ve inkâr gibi insanın Allaha karşı işlediği suçları mahiyet olarak aynı noktada gördügü için O'na göre "Her günah içinde, küfre gidecek bir yol vardır." Bu yüzden küfrün, hakikati örtmek anlamını esas alırsak $^{61}$ günahlar ve inkâr olgusu, hakikati örtmek bağlamında vicdanın sesini susturmaktadırlar. Uzun süre günah ve inkar ahlakı üzere yaşayan bir insan, "kötülükler kalplerini kirletmiştir." ayeti açısından Nursi'ye göre vicdanen bozulmaktadır. ${ }^{62}$ O'na göre vicdanı tamamen bozulmuş biri, insaniyetini kaybetmiştir. Akıl ve zekâ, bireyi tehlikeli bir canavara dönüştürmüştür. Artık bu kişinin tüm davranışları yıkmaya ve zarar vermeye yöneliktir. Kişinin vicdanındaki bozulma ile uğradığı ahlaki çöküntü, Nursi'ye göre İslam hukukunda dini terk eden bir mümine (mürted) verilen ölüm cezasının nedenidir. Zira birey artık beşer olma özelliğinikaybetmiştir. ${ }^{63}$

Erich Fromm'un iki kısımda değerlendirdiği otoriter ve hümaniter vicdan kavramları da Nursi'nin bozuk vicdan tabirine 1şık tutar niteliktedir. Zira Fromm'a göre insan içselleştirdiği dişsal bir otoritenin egemenliği altında vicdani hassasiyeti kaybetmektedir. Kişinin gayesi otoritenin isteklerini yerine getirerek onu memnun etmek olmaktadır. Bu sayede vicdanı rahatlamaktadır. İnsani sorumluluklarına gerçek vicdan değil, dışsal otoritenin talepleri yön vermektedir. ${ }^{64} \mathrm{Hu}$ maniter vicdan ise insana erdem ve mutluluğun yolunu gösteren bir pusuladır. ${ }^{65}$ $\mathrm{Bu}$ bağlamda Fromm insandaki vicdani sapmayı süper ego işlevi gören toplumsal gelenek veya dışsal otoriteye bağlarken Bediüzzaman, otoriteyi içselleştirerek meşruiyet kazandıran insandaki iç dinamiklere dikkat çekmektedir. Said Nursi'ye göre bu dinamikler his, heva ve nefis'tir.

\section{Sonuç ve Değerlendirme:}

Vicdan kavramı antik çağlardan bu yana tartışılmış ve çeşitli açıklamalar getirilmiş bir konudur. Fakat en genel anlamda iki temelde ele alındığını görmekteyiz. Birincisi; vicdanın insan doğasının bir parçası olarak doğuştan var olduğudur. Bu

59 Bakara, 2/7.

60 Said Nursi, Lemalar, Envar neş. İstanbul, 2011, s.9. Said Nursi, İşaratül İ'caz, çev:Abdülmecid Nursi, Diyanet İşleri Başkanlığı, Ankara, 2015, (mühürlenen kalpler bölümü) s.236-238.

61 TDV, Dini Kavramlar Sözlüğü, Ankara, 2010, s.390.

62 Said Nursi, Lemalar, Envar neş. İstanbul, 2011, s.9.

63 Said Nursi, a.g.e. s.122. Said Nursi, Şualar, Envar neş. İstanbul, 2011, s. 588. Said Nursi, Emirdağ lahikas1-1, Envar neş. İstanbul, 2011, s.21.

64 Erich Fromm, Erdem ve Mutluluk, Çev: Ayda Yörükan, İş bankası kültür yay, İstanbul, 1994, s.172-173.

65 Fromm, a.g.e. s. 189. 
bakışa göre vicdan nesnel bir durumdur. Çevresel faktörler ve insanın yaşantılarından etkilense de genel olarak insan doğasında bulunan özerk bir yapıdır. Sezgi ya da ilham yoluyla insana doğru yolu göstermektedir. Diğer bakışa göre vicdan, insanın yaşanmışlıkları çerçevesinde sonradan kazanılan bir tecrübedir.

Said Nursi'nin de vicdanı nesnel olarak ele aldığını görmekteyiz. O'na göre vicdan insandan Allah'a açılan bir penceredir. İnsan ilham yoluyla Allah ile irtibat kurmaktadır. Vicdan aynı zamanda evrendeki nizamın, insanda sezgi yoluyla ortaya çıkan yansımasıdır. Allah tüm varlıkları zorunlu bir nizama tabi kıldığı gibi insanın rolünü de vicdanına bildirerek ona görevini teklif etmektedir. Öte yandan akıl-kalp ve vicdan arasında da dinamik bir ilişki vardır. Kalbe gelen ilahi mesaj, akılda fikir, vicdanda his şeklinde ortaya çıkmaktadırlar.

Nursi'ye göre vicdan, insandaki şuurlu bir fitrattır. Her insanın uyanık vicdanı, iki nedenden dolayı mutlak kudret sahibi bir tanrıyı aşk derecesinde arzulamaktadır. Birincisi; özünde var olan sonsuz sayıdaki emellere karş1lık bulmak için bir yardım noktası, diğeri ise çevresinde kendine tehlike olarak gördüğü düşmanlara karşı bir dayanak noktasıdır. Bu bağlamda Nursi'ye göre vicdan ile Allah arasında kendisinin 'cezbe' olarak ifade ettiği bir ilişki vardır. O’na göre vicdan, tanrısal bir iradenin egemenliğini arzulamaktadır. Bununla beraber vicdan bozulmaya müsait bir cihazdır. Fromm'un içselleştirilmiş dışsal otoritenin etkisiyle ortaya çıkan otoriter vicdan, Nursi'de vicdanın çürümesi, kokuşması şeklinde ifade bulmaktadır. $\mathrm{O}$, bu durumu Kur'ani bağlamda "kalplerin mühürlenmesi" olgusuna bağlamaktadir.

\section{Kaynaklar}

Armstrong, Karen, Tanrı'nın Tarihi, Çev: Oktay Özel, Hamide Koyukan, Kudret Emiroğlu, 2. Baskı, Ankara, Ayraç Yayınları, 2008.

Bilgiz, Musa, Kur'an Açısından Vicdan ve Değeri, Beyan Yayınları, İstanbul, 2007.

Bilmen, Ömer Nasuhi, “Muvazzah İlm-i Kelam”, İstanbul, 1972.

Bahadır, Abdülkerim, insanın anlam arayışı ve din, insan yay, İstanbul, 2002.

Cihan, Mustafa, John Locke'un Ahlak Üzerine Düşünceleri, Kazım Karabekir Eğitim Faküıtesi Dergisi, Sayı:10, 2004.

Cevizci, Ahmet, Etiğe Giriş, Paradigma, İstanbul, 2002.

Çağlı, Ziya, "İslam Dininde Vicdanın Mahiyeti”, Sebilürreşad, c. XII, Çağl1, sy.289.

Deleuze, Gilles, Spinoza Üzerine Onbir Ders, Kabalcı Yay, İstanbul, 2008. 
El-İsfahânî, Râgıb, el-Müfredât, Çıra yay, İstanbul, 2012.

Fromm, Erich, Erdem ve Mutluluk, çev:Ayda Yörükan, İș Bankası Kültür Yay, İstanbul, 1994.

Güngör, Erol, Ahlak Psikolojisi Ve Sosyal Ahlak, Ötüken yay, İstanbul,1995.

Güler, İlhami, Vicdanın Kendini Kandırma Halleri Olarak Vicdansızlık, Eskiyeni, sonbahar, sayı: 19, 2010.

Heidegger, Martin, Varlık ve Zaman, Çev: Kaan H. Ökten. İstanbul, 2009. s. 285 .

İmamoğlu, Abdulvahit, Vicdan Kavramının Psiko-Sosyal Tahlili, Akademik İncelemeler Dergisi, Cilt:5 Sayı:1, 2010.

Kasapoğlu, Abdurrahman, “Kur'an'a Göre Vicdanın Kaynağı ve İşlevleri, Akademik Araştırma Dergisi, Sy. 18, 2003.

Kahveci, Ali, J.J. Rousseau'da Ahlâkî Vicdan ve Değeri, Çukurova Üniversitesi Ilahiyat Fakültesi Dergisi, 12 (1), 2012.

Kuçuradi, İoanna, Etik, Türkiye felsefe kurumu yay, Ankara, 1988.

Kant, İmmanuel, pratik aklın eleştirisi, (çev: İoanna Kuçuradi, Ülker Gökberk, Füsun Akatl1), Türkiye felsefe kurumu, Ankara,1994.

Koç, Zeynep Hümeyra, Vicdanın Ahlaki Ve Teolojik Temelleri, (Yüksek Lisans Tezi) Ankara, 2015.

Locke, John, İnsan Anlığı Üzerine Bir Deneme, çev. V. Hacıkadiroğlu, Kabakı Yay., İstanbul, 1992.

Nursi, Said, Lemalar, Envar neş. İstanbul, 2011.

Nursi, Said, Şualar, Envar neş. İstanbul, 2011.

Nursi, Said, Emirdağ lahikası, Envar neş. İstanbul, 2011.

Nursi, Said, Sözler, Türkiye Diyanet Vakfı, Ankara, 2016.

Nursi, Said, İşaratül İ'caz, çev:Abdülmecid Nursi, DİB, Ankara, 2015.

Nursi, Said, Mesnevi-i Nuriye, çev:Abdülmecid Nursi, DİB, İstanbul, 2015.

Özaydın, Özge, içimdeki ahlak yasası: kant'ın ahlak kuramı üzerine eleştirel bir inceleme, felsefe arşivi, sayı.34, 2011.

Rousseau,“J.J. Emile”, Çev:Mehmet Baştürk-Yavuz Kızılçim, Babil Yay, Erzurum, 2002.

Spinoza, Baruch, Ethica, Çev: Hilmi Ziya Ülken, Dost Kitabevi Yay, Ankara, 2011. 
Şentürk, Habil, İslami Hayatın Psikolojik Temelleri, İz yay, İstanbul, 2013.

Şeriati, Ali, İnsanın Dört Zindanı, Çev: H. Hatemi. İstanbul, 1984.

TDV, Mealli Kuran-1 Kerim, Ankara, 2011.

TDV, İslam Ansiklopedisi, İstanbul, 2013.

TDV, Dini kavramlar sözlüğü, Ankara, 2010.

Türkben, Yaşar, Spinoza'ya göre tanrı ve irade özgürlüğü, Fırat üniversitesi ilahiyat fakültesi dergisi,15,1 (2010)

Ülken, Hilmi Ziya, "Spinoza ve Etika Çevirisi Üzerine Birkaç Söz”, Spinoza, Etika, Fransızcadan Çev: Hilmi Ziya Ülken, 2. Baskı, Ankara, Dost Kitabevi, 2006.

Ülken, H. Ziya, Ahlak, Ülken Yay, İstanbul, 1946. 